\title{
The Link between Information Transparency and Investment Efficiency: A Literature Review
}

\author{
Thi Thanh Huyen Le, M. Fin \\ Faculty of Commerce and Business Administration \\ Van Lang University, Viet Nam
}

Received: October 11, 2018 Accepted: October 26, 2018 Published: November 13, 2018

doi:10.5296/ber.v8i4.13897

URL: https://doi.org/10.5296/ber.v8i4.13897

\begin{abstract}
Investigating the role of information has been recently a hot topic attracting many researchers. A large number of studies have examined the effect of information on cost of capital (Christine A. Botosan, 1997; Diamond \& Verrecchia, 1991; Easley \& O’Hara, 2004), stock price (Welker, 1995), and stock liquidity (Leuz \& Wysocki, 2008). It is demonstrated that the increase in both quantity and quality of information brings benefits to firms as well as the capital markets (Healy \& Palepu, 2001). More specifically, many studies indicate the beneficial influence of information disclosure in improving the efficiency of firm investments (Biddle \& Hilary, 2006; Biddle, Hilary, \& Verdi, 2009; Cheng, Dhaliwal, \& Zhang, 2013; Gomariz \& Ballesta, 2014; Lai, Liu, \& Wang, 2014). This paper presents a review of literature about the relation between information transparency and firms' investment efficiency.
\end{abstract}

Keywords: Disclosure, Investment efficiency

\section{Information Asymmetry and Investment Inefficiency}

Information asymmetry between firms and capital providers is among the factors negatively affecting investment efficiency. The evidence from the study of Huang and Zhang (2012) is that:

“... value-destroying projects, through internal capital investment and external acquisitions, are concentrated in firms adopting opaque disclosure policies” (p.199).

Many prior studies suggest that information asymmetry causes adverse selection and moral hazard. These are main causes leading to imperfect decisions of investing in unprofitable projects and passing up valuable projects, which is known as investment inefficiency (Biddle et al., 2009; Healy \& Palepu, 2001; Lai et al., 2014). Adverse selection is the result of investors' incorrect project assessment, which leads to: investors pay money for negative net 
present value projects, and firms have not enough capital to implement positive net present value projects. Moral hazard relates to managers' activities that are for their interests but might impact negatively on capital providers' wealth.

A firm invests efficiently as its investments are positive net present value projects and reach optimal investment level for growth. However, due to market frictions, the firm's investment might differ from the expectation, exposing underinvestment or overinvestment. Underinvestment is when the firm forgoes investment opportunities which would contribute firm value. Overinvestment is when the firm invests in value-destroying projects (Biddle et al., 2009).

\subsection{Information Asymmetry and Adverse Selection}

Adverse selection is when firms do not have enough capital to finance their profitable projects and investors misallocate their savings in bad projects causing the loss of their wealth. It is known by the capital markets that firm insiders have superior information to outsiders about investment projects, such as capital expenditure, expected cash flow, forecasted risks, and other information. On the one hand, investors, aware of their disadvantageous position, are likely to ask a higher rate of return as compensation for the risk (Easley \& O'Hara, 2004). Therefore, the firm might lose good investment opportunities because of financial constraints. In reality, investors worry about an inadequate interest of return as they spend their money on an investment (Welker, 1995). They tend to reduce stock prices if they are not confident about informed information. Accordingly, the firm share price is lower than it should be.

Moreover, as a consequence of signaling effects, asymmetric information causes a higher external financing cost for firms. To be specific, when the firm issues equity to raise capital, due to asymmetric information, investors might suppose the firm's share price is overvalued. They doubt that the firm wants to take advantage of inflated price by raising equity to gain more incentives from the capital issuance. Consequently, they lower the price that they are willing to pay to buy firm stock. The firm's cost of equity increases (Cheng et al., 2013). From the position of the firm, having inside information, the managers who work for the interest of the current shareholders might refuse to issue new capital if the issuance does not bring benefits to the current shareholders; even when the decision of no issuance means not investing in valuable investment opportunities (Myers, 1984).

In addition, the increase in the firm's cost of equity is also interpreted by the illiquidity of capital market caused by asymmetry information. In the study of Leuz and Wysocki (2008), the authors explain this problem that investors with less information think rationally about the potential loss when they trade with investors who are provided more information. Therefore, uninformed investors are prone to reduce the buying share price as well as increase the selling share price. This is called price protection (Welker, 1995). In the case of large bid-ask spread, the capital markets find them difficult to buy or sell the stocks. Moreover, at a high share price, investors continue worrying about adverse selection. Hence, they ask for a higher return. Turning back to the primary market where the firms desire to raise new capital, they face high cost of capital. As a result, they have to issue more shares with low offering prices 
to raise enough needed capital, or they might forgo the projects. In summary, information asymmetry causes negative reactions of the capital markets, which then affects firms. The firms with positive net present value projects experience external capital constraints and lose their growth opportunities.

\subsection{Information Asymmetry and Moral Hazard}

As explained by Jensen and Meckling (1976), moral hazard means that in the separation between capital users and capital providers, managers do not always act in the best interest of shareholders. Healy and Palepu (2001) also indicate that managers have incentives to expropriate investors' capital. For example, spending for acquisition is a common decision of managers. After the acquisition, the managers directing large firms will be offered higher salaries and gain more incentives. Specifically, a managerial behavior found by Blanchard, Lopez-de-SiIanesb, and Shleifet (1994) is that managers desiring to maintain their power tend to invest cash windfalls, instead of paying out to capital providers, even though there are no favorable investment opportunities. Therefore, firms with high cash flow sensitivity have the tendency to overinvest (Hovakimian \& Hovakimian, 2005). Opler, Pinkowitz, Stulz, and Williamson (1999) also come to the conclusion that "firms with more excess cash have higher capital expenditures, and spend more on acquisitions, even when they have poor investment opportunities" (p.35). Accordingly, in the situation of favorable resources, firms often spend on unnecessary investments which might cause a loss for shareholders. Opaque disclosure makes this an easier option for managers (Biddle et al., 2009; Healy \& Palepu, 2001; Lai et al., 2014).

Information asymmetry brings more advantages to managers for making investment decisions that serve their own purposes, but which might be not in line with shareholders' interests, or may even cause negative impacts on shareholders' wealth. Moral hazard caused by asymmetric information comes from the weak ability of shareholders in monitoring managers' investment decisions. With deficient information, shareholders' ability to assess a project and control managers' activities is limited. Hence, managers are conveniently placed to run the business to maximize their wealth. This is shown in the study of Hope and Thomas (2008). The authors show evidence that once multinational firms are no longer required to disclose their earnings in geographic areas, there is a reduction in their profitability and firm value. Accordingly, nondisclosure, which causes the difference in information between firms' insiders and outsiders, is able to cause a loss of investors' wealth because of mangers' discretion. In summary, asymmetry information, which leads to the problems of adverse selection and moral hazard, is explained as one of main reasons causing firm investment inefficiency.

\section{Disclosure and Investment Efficiency}

As displayed above, the efficiency of a project is affected by information asymmetry between managers and capital providers. The evidence from many prior studies suggests that investment efficiency might be improved by narrowing the gap in information between firm insiders and firm outsiders. Specifically, providing more information to firm outsiders reduces the problems of adverse selection and moral hazard and consequently, firm 
investment is less likely to depart from expected investment, which is known as more efficient investment.

\subsection{Benefit of Disclosure in Reducing Adverse Selection}

Prior studies suggest that disclosure brings investors better ability of assessing an investment's potential benefits, and then supports them in making right investment choices. As a result, this provides sufficient capital for firms with good projects to make investment decisions as well as forces firms with bad projects to give up their investment plans. It is known that investors use the available information of a firm's projects to demand expected return of their investment capital. The required rate of return is lower if the degree of certainty about a firm's potential good business is higher. Based on this, Biddle et al. (2009) and Lai et al. (2014) argue that providing more investment information to capital providers reduces adverse selection through their ability to assess firm value more accurately. The authors explain that by having more information, investors are more sophisticated in evaluating expected firm performance. Consequently, they are confident to make right investment decisions through an increasing required rate of return to firms with bad projects and decreasing this to firms with good projects.

There are many studies acknowledging the benefits of disclosure in reducing adverse selection. Christine A. Botosan (1997) documents the negative relationship between disclosure level and the cost of equity capital. Specifically, he estimates that a one-unit difference in disclosure level leads to a difference of about twenty-eight basis points in the cost of equity capital. Diamond and Verrecchia (1991) also point out that reducing information asymmetry will lead to an increase in a security's current price and a decrease in the cost of capital because investors predict an increased future liquidity of firms' security. In another study, Welker (1995) argues that investors use the bid-ask spread of stock prices to express their evaluation of adverse selection risk. He found a lower bid-ask spread seen in firms' stocks with higher disclosure level compared to firms' stocks with less disclosure level. In addition, when mentioning the benefits of disclosure, with respect to the capital market liquidity, Leuz and Wysocki (2008) indicate that disclosure plays an important role in resolving problems caused by the illiquidity of the capital market. Specifically, in a high disclosure environment, fewer traders have the chance to become privately informed. This reduces the advantages of informed investors as well as the disadvantages of uninformed investors. Hence, the liquidity of the capital markets increases and the firms' cost of capital decrease. To sum up, as declaimed by Biddle and Hilary (2006): "If managers could commit to revealing all of their private information, then outsiders would not ration capital for fear of buying at an inflated price" (p. 967). As a result, a suggestion given by previous studies is that firms can lower their cost of capital by disclosing more inside information to capital markets.

Recognizing the benefits of disclosure, the firms use it as a tool to reduce the cost of capital. Frankel, McNichols, and Wilson (1995) test the hypothesis of whether firms having frequent demand of external funds are more likely to release their management earnings forecast than firms with less demand of this. The finding is consistent with their prediction. Firms that offer 
securities frequently to the markets release more their earnings forecasts in order to gain the benefit of a lower cost of capital. Likewise, doing the study for 34 countries, Francis, Khurana, and Pereira (2005) also provide a similar conclusion with Frankel et al. First, they agree that firms needing greater external financing are likely to undertake a higher level of voluntary accounting disclosure to gain more benefits from the external financing market. Moreover, the authors verify the global effectiveness of disclosure around the world. The conclusion is that lower costs of both debt and equity are found in firms with expanded disclosure policies irrespective of different legal systems and financial systems among the 34 investigated countries. Chang, Dasgupta, and Hilary (2009) examining the relation between the integrity of information with firm financial decision-making also report that the firm raises capital more flexibly as its financial reports show higher quality. Accordingly, the benefit of disclosure in reducing adverse selection is confirmed on the position of the capital market as well as on the position of firm management.

Furthermore, the effect of disclosure on lowering the cost of capital also results from investors' opinion on managers' behavior after they are provided more information. According to Lambert, Leuz, and Verrecchia (2007), the benefit of increased information disclosure is seen in the positive changes of managers' behavior. The authors demonstrate that information disclosure allows the capital providers to direct managers to change to capital allocation choices that generate better future cash flows for investors. Therefore, increasing information gives investors the ability of creating future cash flows, not just perceiving firms' cash flows from managers' investment decisions. In other words, exposing more inside information to the capital markets, managers are likely to make capital allocation choices that should have high coordination between managers and investors. Investors, aware this effect, will ask firms for a lower return.

As a result, in high disclosure environment, firms with positive net present value projects have sufficient capital to finance their investments while firms with negative net present value projects meet capital constraints. The reasons are that investors with transparent information of projects are able to estimate accurately potential benefits, and then requiring reasonable rate of return. Managers are no longer in a position to conceal the real project value from investors. Accordingly, increased disclosure level can reduce overinvestment and underinvestment, which leads to improve investment efficiency.

\subsection{Benefit of Disclosure in Reducing Moral Hazard}

The previous literature agrees that with more information available to investors, managers are less likely to invest in projects that might harm investors' wealth, because the managers' activities are monitored. The argument is that increased disclosure level provides investors a monitoring tool to control managers' investment decisions (Bens \& Monahan, 2004; Biddle et al., 2009; Healy \& Palepu, 2001; Lai et al., 2014). As presented by Hope and Thomas (2008) "an important function of financial disclosures is to provide shareholders a mechanism by which to monitor the activities of managers" (p. 622). In another study by Eng and Mak (2003), the authors state that “... monitoring by outside shareholders may be reduced if managers can provide voluntary disclosure. That is, voluntary disclosure is a substitute for 
monitoring” (p. 330).

The explanation is that on the one hand, shareholders who are provided more information have a greater ability to analyze investment decisions. This strengthens shareholders' right to decision-making and prevents the loss of their wealth in case they identify managers intend to conduct suboptimal projects. On the other hand, once the regulations of increased disclosure are issued, managers' investment choices are clearly exposed to the capital markets, under a greater scrutiny of the external markets and financial experts (Kanodia \& Lee, 1998). In this situation, it is harder for managers to waste their firms' financial resources. Therefore, managers who make investment choices regardless of capital providers' interests are less likely to appropriate shareholders' cash flows to enhance their own welfare. Subsequently, the more project information the capital providers have, the more efficient the project investment will be.

This conclusion is confirmed by the previous literature. The study by Cho (2015) investigates the effect of managerial action disclosure on the efficiency of internal capital allocation before and after the adoption of SFAS 131. SFAS 131 is to help provide more information about firms' structure and performance to investors, which implies that firms adopting SFAS 131 are at a high disclosure level, but would otherwise be at a low disclosure level. The authors found that the firms, which suffer severe agency problems in the pre-SFAS 131 period, witness a greater improvement of capital allocation efficiency after adopting this regulation. In addition, the study of Huang and Zhang (2012) also supports the perspective that high disclosure policy facilitates the control of capital markets on management. The author examines the effect of information transparency on the agency problem through investigating the contributions of liquid asset holding and investment ventures to shareholder value in firms with different disclosure levels. The evidence is that the cash assets are reported at discounted value in firms with lower disclosure level, while this value is improved in firms with higher disclosure level. Accordingly, under the condition of extensive disclosure, managers find it difficult to expropriate firms' cash assets for their own interests; thereby reducing the loss of value to the firm.

\section{Conclusion}

As shown above, information asymmetry creates advantage conditions for managers with bad projects to deceive capital providers about unreal investment benefits. As a result, investors who are weak in project assessment are likely to pass up good projects and fund for bad projects. Healy and Palepu (2001) explain that in order to fund investments, firms try to convince investors about good potential return of the projects, even though these projects might not be optimal ones. Likewise, Cheng et al. (2013) present that it is easy for firms with weak internal control to provide incorrect information to the capital markets, such as overstated revenues or understated costs, in order to seek support from outsiders for their investments which might destroy capital providers' wealth.

To sum up, adverse selection and moral hazard which cause a decrease in investors' wealth might be resolved by providing more inside information from firms to the capital markets. In the environment of information transparency, investors have a better ability to assess firm 
value as well as monitor managers. As a result, suboptimal projects decrease, firm value increases, and capital providers' wealth is built up.

\section{References}

Bens, D. A., \& Monahan, S. J. (2004). Disclosure Quality and the Excess Value of Diversification. Journal of accounting research, 42(4), 691-730.

https://doi.org/10.1111/j.1475-679X.2004.00154.X

Biddle, G. C., \& Hilary, G. (2006). Accounting Quality and Firm-Level Capital Investment. The Accounting Review, 81(5), 963-982. https://doi.org/10.2308/accr.2006.81.5.963

Biddle, G. C., Hilary, G., \& Verdi, R. S. (2009). How does financial reporting quality relate to investment efficiency? Journal of Accounting and Economics, 48(2-3), 112-131.

https://doi.org/10.1016/j.jacceco.2009.09.001

Blanchard, O. J., Lopez-de-SiIanesb, F., \& Shleifet, A. (1994). What do firms do with cash windfalls? Journal of Financial Economics, 36(3), 337-360.

https://doi.org/10.1016/0304-405X(94)90009-4

Botosan, C. A. (1997). Disclosure Level and the Cost of Equity Capital. The Accounting Review, 72(3), 323-349.

Chang, X., Dasgupta, S., \& Hilary, G. (2009). The effect of auditor quality on financing decisions. The Accounting Review, 84(4), 1085-1117.

https://doi.org/10.2308/accr.2009.84.4.1085

Cheng, M., Dhaliwal, D., \& Zhang, Y. (2013). Does investment efficiency improve after the disclosure of material weaknesses in internal control over financial reporting? Journal of Accounting and Economics, 56(1), 1-18. https://doi.org/10.1016/j.jacceco.2013.03.001

Cho, Y. J. (2015). Segment disclosure transparency and internal capital market efficiency: Evidence from SFAS No. 131. Journal of Accounting Research, 53(4), 669-723.

https://doi.org/10.1111/1475-679X.12089

Diamond, D. W., \& Verrecchia, R. E. (1991). Disclosure, liquidity, and the cost of capital. Journal of finance, 46 (4), 1325-1359. https://doi.org/10.1111/j.1540-6261.1991.tb04620.x

Easley, D., \& O'Hara, M. (2004). Information and the cost of capital. Journal of finance, 59(4), 1553-1583. https://doi.org/10.1111/j.1540-6261.2004.00672.x

Eng, L. L., \& Mak, Y. T. (2003). Corporate governance and voluntary disclosure. Journal of Accounting and Public Policy, 22(4), 325-345.

https://doi.org/10.1016/S0278-4254(03)00037-1

Francis, J. R., Khurana, I. K., \& Pereira, R. (2005). Disclosure Incentives and Effects on Cost of Capital around the World. The Accounting Review, 80(4), 1125-1162.

https://doi.org/10.2308/accr.2005.80.4.1125

Frankel, R., McNichols, M., \& Wilson, G. P. (1995). Discretionary Disclosure and External 
Financing. The Accounting Review, 70(1), 135-150.

Gomariz, M. F. C., \& Ballesta, J. P. S. (2014). Financial reporting quality, debt maturity and investment efficiency. Journal of Banking \& Finance, 40, 494-506.

https://doi.org/10.1016/j.jbankfin.2013.07.013

Healy, P. M., \& Palepu, K. G. (2001). Information asymmetry, corporate disclosure, and the capital markets: A review of the empirical disclosure literature. Journal of Accounting and Economics, 31(1-3), 405-440. https://doi.org/10.1016/S0165-4101(01)00018-0

Hope, O.-K., \& Thomas, W. B. (2008). Managerial Empire Building and Firm Disclosure. Journal of accounting research, 46(3), 591-626.

https://doi.org/10.1111/j.1475-679X.2008.00289.x

Hovakimian, A., \& Hovakimian, G. (2005). Cash flow sensitivity of investment. Working paper. City University of New York. http://dx.doi.org/10.2139/ssrn.687493

Huang, P., \& Zhang, Y. (2012). Does Enhanced Disclosure Really Reduce Agency Costs? Evidence from the Diversion of Corporate Resources. The Accounting Review, 87(1), 199-229. https://doi.org/10.2308/accr-10160

Jensen, M. C., \& Meckling, W. H. (1976). Theory of the firm: managerial behaviour, agency costs and ownership structure. Journal of Financial Economics, 3(4), 305-360.

https://doi.org/10.1016/0304-405X(76)90026-X

Kanodia, C., \& Lee, D. (1998). Investment and disclosure: The disciplinary role of periodic performance reports. Journal of accounting research, 36(1), 33-35.

https://doi.org/10.2307/2491319

Lai, S.-M., Liu, C.-L., \& Wang, T. (2014). Increased disclosure and investment efficiency. Asia-Pacific Journal of Accounting \& Economics, 21(3), 308-327.

https://doi.org/10.1080/16081625.2012.741791

Lambert, R., Leuz, C., \& Verrecchia, R. E. (2007). Accounting Information, Disclosure, and the Cost of Capital. Journal of accounting research, 45(2), 385-420.

https://doi.org/10.1111/j.1475-679X.2007.00238.x

Leuz, C., \& Wysocki, P. (2008). Economic Consequences of Financial Reporting and Disclosure Regulation: A Review and Suggestions for Future Research. Social Science Research Network. http://dx.doi.org/10.2139/ssrn.1105398

Myers, S. C. (1984). The capital structure puzzle. The Journal of Finance, 39(3), 575-592. https://doi.org/10.1111/j.1540-6261.1984.tb03646.x

Opler, T., Pinkowitz, L., Stulz, R., \& Williamson, R. (1999). The determinants and implications of corporate cash holdings. Journal of Financial Economics, 52(1), 3-46.

https://doi.org/10.1016/S0304-405X(99)00003-3

Welker, M. (1995). Disclosure Policy, Information Asymmetry, and Liquidity in Equity Markets. Contemporary accounting research, 11(2), 801-827. 
https://doi.org/10.1111/j.1911-3846.1995.tb00467.x

\section{Copyright Disclaimer}

Copyright for this article is retained by the author(s), with first publication rights granted to the journal.

This is an open-access article distributed under the terms and conditions of the Creative Commons Attribution license (http://creativecommons.org/licenses/by/3.0/). 